\title{
Norske inspirationer i dansk kortprosa
}

Man kan begynde historien om dansk kortprosa mange steder: de korteste og mindst regulært eventyragtige af H.C. Andersens tekster, fx "Det nye Aarhundredes Musa" eller teksterne i Billedbog uden Billeder, Søren Kierkegaards "Diapsalmata" fra Enten-Eller, Johannes V. Jensens prosaforfatterskab, Peter Seebergs, Raymond Carvers, Ernest Hemmingways. Man kan også lade den begynde med de islandske sagas ordknappe stil, fablen, det romantiske fragment, den amerikanske short story eller short short story'en. Men man kan også lade den begynde i Norge. Det perspektiv er der ikke mange der har været opmærksomme på. ${ }^{1}$

\section{Kortprosamysteriet}

I nogle år - fra sidste halvdel af 1990'erne til en tre-fire år ind i det nye årtusinde - blev der skrevet en del dansk kortprosa. Og i nogle år - en lille smule, men ikke meget forskudt i forhold til den hektiske kortprosa-produktion - blev der også skrevet en hel del om dansk kortprosa. Der blev også skrevet kortprosa der kunne læses som kortprosa om kortprosa. Fx skrev Morten Søndergaard i kortprosa-samlingen At holde havet tilbage med en kost (2004) en kort tekst, som man kan læse som et bud på hvor kortprosaen kom fra. Teksten hedder "Foran biblioteket", og den lyder i sin helhed sådan her:

4 I døråbningen ind til Nationalbiblioteket i Buenos Aires spørger Borges katten som bor der, om han må have lov at gå forbi den. "Det er muligt," svarer katten, "men du skal vide at jeg er mægtig. Og jeg er kun den underste dørvogter; fra sal til sal står der dørvogtere, den ene mægtigere end den anden. Allerede den tredje kan ikke engang jeg tåle synet af." Borges nikker og går forbi den ind i biblioteket. (Søndergaard 2004: 39).

Jorge Louis Borges møder Franz Kafka. ${ }^{2}$ Sådan kan man løse kortprosamysteriet: Den danske kortprosa er en blanding af inspirationer fra to store internationale for- 
fattere, forfattere der begge har skrevet korte tekster, Borges og Kafka. Det er ikke den mest hensigtsmæssige måde at løse det på. (Og i en parentes vil jeg, inden jeg går videre, lige bemærke at jeg ikke beskylder Morten Søndergaard for at ville løse kortprosamysteriet på den måde i sin tekst. Teksten handler muligvis overhovedet ikke om kortprosa. Teksten er måske nærmere et bud på en forståelse af Borges' forfatterskab eller en opridsning af nogle af Søndergaards egne inspirationer. Ikke desto mindre kan den læses som en kortprosa-tekst om kortprosa).

Borges møder Kafka. Om det nu er Søndergaards bud på en forståelse af kortprosa, hans egen kortprosa eller noget helt tredje eller fjerde er ikke så vigtigt her. Borges møder Kafka er en typisk måde at fremstille dansk litteratur - og ikke bare, men også dansk kortprosa - på: Man sammenligner dansk litteratur med solidt kanoniseret udenlandsk litteratur. På den måde er dansk kortprosa kommet til at ligne Poe, Baudelaire, Beckett, Kafka, Borges, Carver og så videre, og så videre. Og nogle gange Johs. V. Jensen og Seeberg. Men kun yderst sjældent norsk litteratur. ${ }^{3}$ Og hvorfor nu ikke det? Det er der sikkert en række gode grunde til. For det første er det ikke givet at danske litteraturforskere og -kritikere er særligt velorienterede i norsk eller for den sags skyld i skandinavisk litteratur. Mange danske litterater kender ganske enkelt Poe, Baudelaire og Beckett betydeligt bedre end de kender Paal-Helge Haugen, Jan Erik Vold og Kjell Askildsen. Måske kender de også den kanoniserede, klassisk-moderne litteratur bedre end samtidslitteraturen. For det andet viser det belæsthed at kunne sammenligne en ny dansk kortprosa-samling med Kafka, Borges og Beckett. Ved således at lade solen skinne på den forfatter man sammenligner med et udenlandsk litterært ikon, får man også selv en smule andel i lyset. Og fordi det jo er forskerne og kritikerne der laver sammenligningerne, er det i realiteten væsentligere hvad de véd, tror, mener og foretrækker, end hvad den litteratur de sammenligner med anden litteratur, når det kommer til stykket er inspireret af eller ligner - hvilket jo på den anden side ikke betyder at sammenligningerne er forkerte. Det er de ofte ikke, men de er ofte heller ikke de eneste rigtige, for tekster er samlingspunkter for en række inspirationer.

Lars Bukdahl, som ganske givet er den kritiker der har læst mest dansk litteratur i kortprosa-perioden i dansk litteratur, har også skrevet om kortprosa, først i oversigtsartiklen om "Ritter Sport-Generationen" fra 1999. "Ritter Sport-Generationen" er en vigtig oversigt over dansk kortprosa, og artiklen havde da også på et vist tidspunkt næsten klassikerstatus blandt dansklærere - og det var med god grund den fik det. Her fik man, med små kommentarer til de firkantede kortprosa-tekstbokse, alle navnene: Lene Henningsen, Christina Hesselholdt, Christian Dorph, Christina Englund, Morten Søndergaard, Niels Lyngsøe, Kirsten Hammann, Katrine Marie Guldager, Thomas Thøfner, Carsten René Nielsen, Helle Helle, Mads Storggaard Jensen, Thøger Jensen, Peter Adolphsen og nogle flere som Bukdahl nævner ved at nævne at dem kunne man også have nævnt. Det er alt sammen godt, men der er en svaghed ved teksten: Man får næsten den opfattelse at kortprosa er et rent dansk anliggende. Og lige så lidt som den danske kortprosa er et konglomerat af Borges og Kafka, lige så lidt er den rundet udelukkende af dansk muld. Med tilslutning henviser Lars Bukdahl til den konstruktion som Jeppe Brixvold og Hans Otto Jørgensen med deres udvalg konstruerede i den vigtige Antologi over dansk kortprosa fra 
1998. Historien begynder, som Lars Bukdahl skriver, "hos mytiske og mystiske jyder som Johs. V., Knud Hjortø [der, når ret skal være ret, er sjællænder], Albert Dam i århundredets begyndelse" og kører så ellers op gennem den danske litteraturs historie (Bukdahl 1999: 33). Lars Bukdahl gør med andre ord Jørgensen og Brixvolds udvalg i deres antologi til et bud på en historie for den danske kortprosa. Det er det ikke. Antologien er en antologi over dansk kortprosa, og derfor er der helt naturligt ikke udenlandske eksempler med. At der ikke er udenlandsk kortprosa med i Brixvold og Jørgensens antologi, betyder ikke at der ikke er en mere markant inspiration fra udenlandsk kortprosa end fra fx Knud Hjortø på færde i den aktuelle danske kortprosa. Det er der helt afgjort.

I Generationsmaskinen er der også et grundigt afsnit om dansk kortprosa. Afsnittet hedder "Kortprosamysteriet". "Kortprosamysteriet" er blandt det bedste der er skrevet om dansk kortprosa, så hvis man kun skal læse en tekst om dansk kortprosa, så skal det være Bukdahls afsnit i Generationsmaskinen. Her skriver han: "Kortprosa har været et kodeord i den yngste litteratur siden ca. 1998-1999, men hvor kom det dog fra?" (Bukdahl 2004: 211). Ja, hvor kom kortprosaen fra? Og, især, hvor kom begrebet kortprosa fra? Og hvordan gik det til at kortprosaen og begrebet kortprosa pludselig var der, næsten som noget der dukkede op ud af det blå, og nu pludseligt fandtes som den naturligste ting i den litterære verden? Især det sidste spørgsmål har Lars Bukdahl en række gode svar på.

Bukdahl citerer en tekst fra Camilla Christensens Stakkels bobcat fra 2002 og konkluderer at teksten "er et stykke kortprosa, kan vi med stor sikkerhed fastslå i dag, men det ville vi ikke kunne have gjort for bare syv eller otte år siden, for på det tidspunkt fandtes størrelsen ikke, ikke rigtigt" (Bukdahl 2004: 212). Det er en tankevækkende pointe at man blot få år tidligere forsigtigt ville have talt om prosadigt, prosalyrik eller blot om en hybrid eller et eksperiment. ${ }^{4}$ Lars Bukdahl nævner tre litterære indsatser som initiale for dansk kortprosa - og igen er perspektivet udelukkende dansk litteratur: For det første: Louis Jensens tre samlinger uden genrebetegnelse, At læne sin kind mod verden (1991), Men i lyset hende (1992), Det øverste af en længsel (1994), som kom samtidig med at Jensen også startede sin serie af firkantede historier for børn og voksne med bogen Hundrede historer; for det andet: Hans Otto Jørgensens Den bronzefarvede kalkun (1993); for det tredje: Brøndums Encyklopædi. Af de tre indsatser fremhæver Lars Bukdahl, helt korrekt, tror jeg, Hans Otto Jørgensens kortprosa-bog, der udkom på After Hand fordi ingen af de forlag Jørgensen ellers udgav på, ville udgive bogen. Helt korrekt fordi Louis Jensens markante bidrag ganske uretfærdigt ikke rigtigt blev bemærket og fordi Brøndums Encyklopædi også var en masse andre ting end kortprosa - og det var disse ting man især bemærkede.

Efter disse tre indsatser skulle man have beskrevet det nye fænomen. Igen fokuserer Lars Bukdahl på tre indsatser. For det første, skriver Bukdahl, var der et temanummer af Passage, nr. 25 fra 1997, der handlede om "Kort prosa". Og her gør man, som Bukdahl også gør opmærksom på, rigtigt i at bemærke mellemrummet mellem de to ord: Den korte prosa var endnu ikke blevet til kortprosa. I nummeret er der introduktioner til en række internationale "kort prosa-forfatterskaber", Robert Walzer og William Carlos Williams, fx. Og der er en enquete af danske forfattere i et udvalg som 
Bukdahl kalder "kuriøst, men absolut kvalificeret" (Bukdahl 2004: 216). Nummeret er vigtigt, men Bukdahl overser et af nummerets vigtigste indsatser. I lederen introducerer redaktionen Walter Höllerers artikel "Die Kurze Form der Prosa" fra tidsskriftet Akzente, nr. 2, 1962. I artiklen opstiller Höllerer 7 punkter som karakteriserer den korte prosa, som også Höllerer skriver om i stedet for om kortprosa. Der bliver ikke fulgt op på artiklen i temanummeret, men i en forskningsmæssig og forståelsesmæssig sammenhæng var det væsentligt at få denne tekst bragt ind i debatten om dansk kortprosa. ${ }^{5}$ Den næste indsats er den væsentligste: Hans Otto Jørgensens og Jeppe Brixvolds Antologi af dansk kortprosa, der blev udgivet af Dansklærerforeningen i 1998. Efter udgivelsen af denne antologi, som er en kraftpræstation på området, kunne man ikke længere være i tvivl om at der var noget der hed kortprosa - i et ord i Danmark. 59 forfattere (fra J.P. Jacobsen til Peter Adolphsen, anført efter fødselsår) blev præsenteret i antologien, der havde en klar overvægt af nyere forfatterskaber. Christina Hesselholdt, Morten Søndergaard, Pablo Henrik Llambías, Merete Pryds Helle, Katrine Marie Guldager, Simon Fruelund, Jeppe Brixvold og Peter Adolphsen var, for nu blot at nævne nogle af de yngre forfattere i antologien, med. "Hvordan det nu end lod sig gøre, lå kortprosa lige på tungen af den litterære tidsånd i 1997-98-99, alle forholdt sig undrende over for faktummet, men ingen kunne komme uden om det", konkluderer Lars Bukdahl (Bukdahl 2004: 219). Året efter udgav Brixvold og Jørgensen Kortprosa 1999. Efter den første, meget stærke og for mange øjenåbnende, antologi virkede Kortprosa 1999 måske en smule skuffende, men set på afstand og i en litteraturhistorisk sammenhæng er antologien en kraftpræstation helt på linje med den første antologi. 90 forskellige forfattere bidrog til antologien, og det er godt set af Lars Bukdahl, der som den eneste har sat den anden antologi ind i dens fortjente litteraturhistoriske sammenhæng, at de 90 bidragydere er det bedste udtryk for at kortprosa nu, i 1999, findes: "90! Så mange mente, at de nok kunne bidrage med et bud på en genre, der bare få år før faktisk var ikke-eksisterende”, skriver han (Bukdahl 2004: 220). Og så konkluderer han: "Ingen så den komme, men kortprosaen findes nu ubetvivleligt" (Bukdahl 2004: 222). Og alene det forhold at Brixvold og Jørgensen med deres projekt fik 90 forfattere til at skrive kortprosa, har givetvis haft stor betydning for mængden af kortprosa der blev skrevet de følgende år.

Der er masser af gode iagttagelser og en hel række gode svar på hvor kortprosaen kom fra, dengang i slutningen af 1990'erne, i Lars Bukdahls to tekster om dansk kortprosa, men perspektivet er kun dansk, så der er intet om den norske forbindelse. Den kommer jeg med et bud på.

\section{Den norske forbindelse}

Det er ikke helt præcist at tale om dén norske forbindelse, for der er ikke én norsk forbindelse, men en fire, fem - mere og mindre væsentlige - norske forbindelser i spil i forbindelse med dansk kortprosa. For det første er der norsk kortprosa fra 1960'erne. For det andet er der Kjell Askildsen. For det tredje norske forfattere fra 1990'erne som fx Ole Robert Sunde og især Tor Ulven. For det fjerde er der PaalHelge Haugens punktroman Anne fra 1968. Og for det femte Merete Morken Andersens punktroman Fra fra 1988. 
Og så er der en mulig sjette forbindelse, som jeg kort vil strejfe før de andre fem norske forbindelser: Det ser ud som om ordet kortprosa har været brugt tidligere i Norge end i Danmark. Vel at mærke som en betegnelse for den type kortprosa vi i Danmark fra omkring 1997 har omtalt som kortprosa - og om det er udtryk for at fænomenet som begrebet dækker, har eksisteret tidligere i Norge end i Danmark, eller om det blot er blevet navngivet tidligere, er vanskeligt at afgøre, og diskussionen kan nemt ende det samme sted som diskussionen om det var hønen eller ægget der kom først. Ikke desto mindre betyder det at der er en sandsynlighed for at selve begrebet kortprosa er gledet ind i dansk litterær sprogbrug fra norsk.

I 1995 skrev Bjørn Aagenæs en artikel med titlen "Norsk kortprosa (60-90)" til Dansk noter. Han indleder artiklen med en kort henvisning til 1960'ernes norske kortprosa, Dag Solstad, Jan Erik Vold og Paal-Helge Haugen, men skriver ellers primært om tre 90'er-forfattere, Tor Ulven, Jon Fosse og Eva Jensen. Det mest bemærkelsesværdige ved Aagenæs' artikel er dog, i det mindste i denne sammenhæng, at han bruger begrebet kortprosa med en selvfølgelighed som antyder at enhver ved hvad det dækker. Og det gjorde enhver, som Lars Bukdahls gennemgang har vist, ikke i 1995, ikke i Danmark. Aagenæs citerer desuden i sin artikel det eneste interview Tor Ulven, der selv skrev kortprosa, gav. Her sagde Ulven i 1993: "Kortprosaen gir meg muligheten til å skrive konsentrerte tekster fra tre linjer til tre sider. Den har en fortetning som likner diktet, men har samtidig en ledighet og en åpenhet som ligner historien", og så er vi straks i nærheden af noget der minder om den danske kortprosa lidt senere i årtiet (Aagenæs 1995: 23). Det tyder altså på at begrebet har været i almindeligt omløb tidligere i Norge end i Danmark - og selv om navngivningen af et fænomen vel ikke afstedkommer inspiration, så har selve udpegningen af fænomenet betydning for fænomenets udbredelse. Men nu tilbage til de fem andre norske forbindelser.

For det første: En række norske forfattere, blandt andre Jan Erik Vold og Dag Solstad, skrev kortprosa i 1960'erne. Det er et åbent spørgsmål hvor meget disse tekster er blevet læst i Danmark, og derfor er det også et åbent spørgsmål om den norske kortprosa fra 1960'erne har givet anledning til nogen direkte inspiration. Der er på den anden side ikke tvivl om at norske kortprosaister punktromanforfattere fra 1990'erne har kendt og læst Volds og Solstads tektser, og disse norske kortprosaister og punktromanforfattere fra 1990'erne har de danske kortprosaister læst. Derfor vil jeg citere en prægnant tekst af Dag Solstad fra 1967. Teksten er vigtig i en norsk litteraturhistorisk sammenhæng, hvor den ofte blevet opfattet som et program for Profil-gruppen, og den kunne næsten også have fungeret som program for den hyper-realistiske eller minimal-realistiske danske kortprosa i 1990'erne. "Vi vil ikke gi kaffekjelen vinger”, hedder Dag Solstads tekst. Den er med rette placeret som den første tekst i kortprosa-samlingen Svingstol fra 1967:

46 Før var vi drømmere og derfor blinde. Vi leste aviser, verdenshistorie, kriminalromaner og oppdaget ikke forskjellen. Før søvnen var gnidd av øynene, steg vi til frokostbordet og uten å si: bord, dekk deg. Vi tenkte på nettenes uhyggelige drømmer og var fornøyd med det. Men årene gikk og endelig forandret vi oss. // En dag forlot vi sengene, holdt strømpene i hånden og merket at porene i fingrene fikk ull. Vi slo badekranene på og kjente 
susningen av vann mot neseborene. Vi bodde i blokk og når alle stod opp til samme tid syntes vi badekranene dannet et orkester. // Vi var blitt muntrere. Tingene klebet seg ikke lenger til oss som skodde. De hilste oss velkommen når vi inntok frokostbordet. // Da gikk det opp for oss at også kaffekjelen var der. Vi så den plutselig på frokostbordet. Et stort blankt dyr mellom kopper, asjetter, sardinbokser, syltetøy. Den sto på voksduken. Underlig: Ingen sa noe. Hadde et barn vært mellom oss, og det hadde ikke vært umulig da, ville det kanskje ropt: Se, der er en kaffekjele. // Det var en forunderlig morgen. Vi kunne begynne å leke. Kaffekjelen lignet et tårn mellom alle de andre tingene. Vi lo til hverandre, laget papirfly av serviettene som vi lot sveve over tårnet og ned på gulvet, i sjøen der nede. Vi rørte fingrene i bunnen av kaffekoppene og spådde hverandre om fremtiden. Enda vi ikke trodde på det vi sa, var det fint å røre fingrene i kaffegruten. // Siden så vi ordentlig på kaffekjelen og fortalte hverandre hva vi syntes den lignet. Vi kom for sent til arbeidet og oppdaget at det ikke var den katastrofen vi hadde sagt, men aldri trodd det var // Ser man nøye på kaffekjelen, kan tuten være et nebb og håndtaket stjerten med alle de brusende fjærene. Gir vi kaffekjelen vinger, blir den en fugl som kan fly opp under taket, svive rundt lampekuplen eller, hvis vinduet er åpent, gjennom det og ut i den blå dagen. // Vi ville gi kaffekjelen vinger. På arbeidsplassene tegnet vi utkast til vinger og om kveldene diskuterte vi og sammenlignet. // Til vi en morgen forsto at vi for alltid måtte slutte å drømme. Da ble vi fylt av en ømhet for verden og sa: Vi vil ikke gi kaffekjelen vinger. Vi vil ikke forandre tingene våre til fugler og blomster. Vi vil la kaffekjelen være kaffekjelen og se den stå på frokostbordet, blank av aluminium og fylt med rykende kaffe. Vi vil ta et godt tak i håndtaket, løfte den på skrå over bordet, bevege den langsomt mot alle koppene og fylle dem en etter en med svart kaffe som vi drikker. (Solstad 1967a: 7f)

Dag Solstad skrev ikke blot (til tider programmatisk) kortprosa, men også teoretiske tekster, som, givetvis med inspiration fra blandt andet den franske ny-roman-forfatter og -teoretiker Alain Robbe-Grillet, problematiserede en overdreven symbolisering i litteraturen. Den overdrevne symbolisering blev også problematiseret i Danmark i midten af 1960'erne, fx af gruppen omkring tidsskriftet $t a$ ', hvor ikke mindst HansJørgen Nielsen spillede en væsentlig rolle. I Danmark førte denne kritik dog til en anden kunstnerisk praksis end den gjorde i Norge, hvor forfatterne eksperimenterede blandt andet med hverdagselementer i prosaen, hvilket førte til en art minimal-realisme. ${ }^{6}$ I Danmark førte opgøret med symboliseringen og med en kunstnerisk og filosofisk dybdemodel kunstnerne i retning af indholdsmæssigt tømte digte og konkret lyrik. I artiklen "Det trivielle/det fantastiske - flukt/akseptasjon" fra 1967 citerede Solstad med tilslutning den svenske forfatter Artur Lundkvist for en bemærkning om at "Norrskenet är sällsyntare i verkeligheten än i dikten" (Solstad 1967b: 96). Dag Solstads artikel er et forsvar for hverdagen som en del af litteraturen, og den er et angreb på den litteratur der, som Solstad skriver, henter sine "metaforer fra jakt- og fiskeforeningens virkelighetsområde" i stedet for i det daglige liv, hvor der er flere "stikkontakter, lampeskjermer, telefonledninger" og så videre end der er nordlys (ibid.). Solstad konkluderer at det er en banal affære at leve. Livet består ikke af store begivenheder, som litteraturen vil foregøgle os i en "oversymbolisering av alt" og i en fremhævelse af de dybe sandheder som det egentlige og det virkelige (Solstad 1967b: 97). En kaffekande er en kaffekande, og, kunne man sige med henvisning til Helle 
Helles tidlige korte tekster, en fasan er en fasan (eller er den nu også det? - det var en overgang spørgsmålet der blev stillet af enhver dansklærer med respekt for sig selv).

For det andet: Erik Skyum-Nielsen skriver i sin bog om 1990'ernes litteratur, Engle i sneen, at han på et tidspunkt sidst i 1990'erne spurgte forlæggeren Torben Madsen hvilke forfattere de unge prosa-debutanter læste. Svaret, der ifølge Skyum-Nielsen faldt prompte, var "Peter Seeberg, Kjell Askildsen, Raymond Carver" (Skyum-Nielsen 2000: 197). Lars Bukdahl nævner også Peter Seebergs forfatterskab som en afgørende inspiration i forbindelse med dansk kortprosa, for som Bukdahl skriver, så stod ét fast midt i alle forsøgene på at skrive og beskrive kortprosa: "Seeberg skrev kortprosa, og det var godt, og det afgav så effektiv aura til både selve ordet og til de yngre og unge udøvere, der direkte eller indirekte henviste til Peter den Store" (Bukdahl 2004: 219). I slutningen af 1990'erne var det også tydeligt at Raymond Carver blev vigtigere og vigtigere som inspiration i dansk litteratur. Det blev blandt andet understreget med oversættelsen af novellerne i Hvad vi taler om når vi taler om kærlighed i 1994. Og talte vi ikke om kærlighed, så talte vi i hvert fald om Carver, kortprosa og minimalisme.

Og så er der det norske indslag i triaden, Kjell Askildsen. Erik Skyum-Nielsen skriver i Engle i sneen om Raymond Carver og Kjell Askildsen at deres tekster udmærker sig ved en "fænomenologisk registrerende stil, der balancer hårfint mellem det modernistisk abstrakte og det hyper-realistisk konkrete", og om Askildsen at han "i sin knappe prosa [beskriver] mennesker, der er bedst til at tie" (Skyum-Nielsen 2000: 197f). Man kan også formulere Askildsens kunstneriske position med et citat fra en af Askildsens egne tekster, "Thomas F's siste nedtegnelser til almenheten" fra samlingen med den samme titel (1983): "den som sier mye har ikke sine ord i behold" (Askildsen 1999: 275). I forbindelse med et seminar i Århus om Askildsens forfatterskab indledte Askildsen selv med en korrektion. I en lille folder om seminaret havde man, troede man, citeret passagen fra "Thomas F's siste nedtegnelser til almenheten". Det havde man ikke helt, viste det sig. Stedet, der af og til citeres og bruges til at karakterisere Askildsens forfatterskab, var i folderen blevet til "den der siger for meget har ikke sine ord i behold". I forlængelse af den citerede passage tænker Thomas også, at "det er altfor mange ord i omløp i verden", og folderen havde altså sat et for for meget i omløb (ibid.). Det lille for gør en forskel, for, som Askildsen sagde: “'Den der siger for meget', er en truisme, det er en banalitet. Det kunne Thomas F aldrig sige." ${ }^{\prime}$ Og det kunne Askildsen aldrig skrive. I Askildsens forfatterskab bliver der ikke sat flere ord i omløb i verden end nødvendigt.

Alligevel kan man ikke uden videre forstå Kjell Askildsen som kortprosaist. Forfatterskabet er primært et novelleforfatterskab, med punktvise tendenser i retning af kortprosa. På trods af det er der ikke tvivl om at de danske 90'er-kortprosaister kunne lære en hel del af knapheden og præcisionen hos Askildsen, når de skrev kortprosa. Noget tyder på at de gjorde det. I hvert fald har vi Torben Madsens (og Erik Skyum-Nielsens) ord for at de yngre forfattere i anden halvdel af 1990'erne rent faktisk læste Kjell Askildsen. Det kan man se, fx i Helle Helles minimal-realistiske stil. Måske også i Simon Fruelunds tekster i Mælk fra 1997, og i Thøger Jensens kortprosa, fx i den meget overbevisende debut I vores familie kan vi ikke lide ubåde fra 1998. Jeg ved fra en samtale med Askildsen at han og Helle Helle har læst 
hinandens bøger, og jeg ved også fra samtaler med Thøger Jensen at han har læst Askildsens bøger og været begejstret for dem. Kjell Askildsen kan med andre ord meget nemt være en af de væsentligste inspirationerne for den danske minimalrealisme og dermed for en væsentlig gren af dansk kortprosa. Kjell Askildsen er en forfatter der har et lille, men trofast publikum, ikke mindst blandt andre forfattere. Han er muligvis en forfatter der virker lidt i det skjulte. Og selv om alle på et tidspunkt i 1990'erne snublede over hinanden for at nævne Peter Seeberg og Raymond Carver som inspirationer, tror jeg ikke at man skal undervurdere betydningen af Askildsen kompromisløse og ukorrumperede eksempel.

For det tredje: Også i Norge blev der i 1990'erne skrevet en del kortprosa. Ole Robert Sunde skrev fx i 1996 en bemærkelsesværdig kortprosa-samling om All verdens småting - titlen kunne, nøjagtig som Dag Solstads kaffekande-tekst, fungere som program for dansk minimal-realistisk kortprosa. Og selv om vi med Ole Robert Sundes kortprosa-samling om alle verdens småting måske ikke lige fik stikkontakter eller telefonledninger ind i litteraturen, så fik vi en række fine registreringer. Om "Lampskinn over et gulv" hed det fx (og jeg citerer hele teksten):

4 Den unøyaktige parallellen, hva er det? Over, eller nedenfor kanten av et teppe, ser jeg et smalt lampeskinn, det er ulikt fra lampen og lyset i den, samtidig kommer dette skinnet fra denne lampen, og jeg tenker på hvor vi skal gå for å finne gulvets eget lys, der hvor det er mørkt og ikke helt lyst, et mellomlys, så å si, fra hvor, det vet du vel, dets store indre, du mener det ytre, dets veldige skinn, tryllet fram fra barken og rullet ut $i$ all sin hardhet, og forandret, omgjort til det vi ikke oppdager, inne i stammen og tildekket med sin svake glød? (Sunde 1996: 25)

En anden nordmand, Tore Renberg, udgav også overbevisende samlinger af kortprosa, blandt andet Sovende floke fra 1995. Her kunne man læse en ganske kort - men også, synes jeg, ganske virkningsfuld kortprosa-tekst. Teksten hedder "Konfyr", og lyder i sin helhed: "KONFYR, du sa konfyr, du var liten, munnen din formet seg i et kyss du ikke kjente, og du sa pappa, konfyr" (citeret efter Ipsen 2003: 127). $\varnothing$ jeblikket er fint indfanget i en gestus (munden, der formes som til et kys) og et ord (det forkert udtalte konfyr). Det traditionelt ikke betydningsfulde bliver i teksten betydningsfuldt - eller rettere så bliver det det eneste der er i teksten, betydningsfuldt eller ej.

Jon Fosse udgav i 1994 samlingen Prosa frå ein oppvekst. Jeg skal blot citere en enkelt tekst fra samlingen. Teksten hedder "Øksa", og den lyder i sin helhed: "Ein dag faren kjeftar på han, går han inn i vedskjulet og hentar den største øksa, han ber den inn i stova, set den frå seg attmed farens stol og så ber han far sin om å drepe seg. Faren blir som ventande kan vera berre endå sintere" (citeret efter Aagenæs 1995: 24). Jeg kunne sagtens forstille mig Hans Otto Jørgensen skrive en tekst som denne. Der er med andre ord om ikke andet så en slags åndeligt fællesskab mellem centrale norske og danske forfattere. Det er næsten utænkeligt at der ikke også har været tale om en mere konkret udveksling.

I forhold til dansk kortprosa er Tor Ulven givetvis vigtigere end Ole Robert Sunde, Tore Renberg og Jon Fosse som inspiration. Tor Ulven er det man ofte kal- 
der en forfatternes forfatter, en forfatter som ikke nødvendigvis er meget læst i almindelighed, men som læses af andre forfattere og litterater. Derfor er en forfatternes forfatter naturligvis væsentlig hvad inspiration angår. Tor Ulven er ikke nogen undtagelse fra denne regel. I 1992 udgav Den Blå Port - et tidsskrift som man kan beskrive som et forfatternes tidsskrift, der bliver lavet af forfattere og læst af forfattere - et temanummer om skandinavisk litteratur (nr. 22). I nummeret skrev Christina Hesselholdt en artikel om netop Tor Ulven. "Vi, sammenblandede" hed artiklen, og den handlede, som undertitlen angav, "Om individualitetens opløsning i Tor Ulvens Gravgraver". Christina Hesselholdt argumenterede for at man, fordi der er referencepunkter mellem de enkelte fragmenter i bogen og fordi der er "en tematik i bogen, der cirkler omkring at erindre og at grave", kan opfatte Ulvens bog som en roman, også selvom bogen består af "en række tekststykker, helt præcist 82, ikke nummererede, men adskilt af hvide mellemrum" (Hesselholdt 1992: 22). Gravgraver befinder sig med andre ord mellem det man nogle år senere ville beskrive som henholdsvis punktroman og kortprosa. Beskrivelsen af Tor Ulvens bog, som Christina Hesselholdt i øvrigt oversatte til dansk i 2002, kunne næsten passe på Hesselholdts tidlige bøger, især de to første bøger i den såkaldte Marlon-trilogi, Køkkenet, gravkammeret \& landskabet (bemærk gravkammeret i titlen - er det en reference til Ulvens titel?) fra 1991 - det vil sige året før hendes Ulven-artikel - og Det skjulte fra 1993, der jo altså så er udgivet året efter artiklen. Med det kendskab til Ulven som vi kan aflæse konkret i artiklen og oversættelsen, er det utænkeligt at Hesselholdt - og, fordi Hesselholdt er en central forfatter i dansk litteratur, med hende flere andre unge forfattere - ikke også har kendt til Tor Ulvens andre samlinger af decideret kortprosa, fx Fortæring fra 1991. Her kunne man blandt andet læse dette lille kortprosa-mesterværk uden titel:

Ikke noe annet enn at vi om formiddagen, eller kanskje det var tidlig på ettermiddagen, ihvertfall før det hadde begynt å mørkne, sto nede i en kald vaskekjeller med store tomme skyllekummer, en rusten jernrist i sementgulvet, og snakket om det som snart skulle skje. Blekt lys fra de små rutene høyt oppe på veggen. Kanskje snødde det litteratur der ute. Ingen erindring om selve kvelden, om middagen, lysene på det pynede treet, alle gavene og så videre. Bare denne forventningen, i vaskekjelleren, hvor de dempede stemmene våre klang hult og rått og fremmed. (Ulven 1991: 13)

Tor Ulven har haft og har fortsat en virkningshistorie i dansk litteratur, fx skriver Mads Eslund på sin blog at han har oversat Stein og speil fra 1995 til dansk, men har haft vanskeligt ved at få oversættelsen afsat til udgivelse.

For det fjerde: Paal-Helge Haugen udgav i 1968 punktromanen Anne. Og i forbindelse med Haugens betydning for dansk kortprosa, vil jeg igen tage udgangspunkt i et temanummer af Den Blå Port, nr. 36 fra 1996. Solvej Balle og Christina Hesselholdt var redaktører af tidsskriftet. Temaet var kortprosaens norske halvfætter, punktromanen. ${ }^{8}$ De to redaktørers leder er interessant. De indleder med en aflæsning af litteraturen i midten af 1990'erne: "Fragmentarisk. Punktuel. Det er ord, der i disse år ofte tages i brug ved beskrivelsen af nyere prosa - i anmeldelser, oversigtsartikler, forord til antologier - og som regel forudsættes det bekendt, hvad 
ordene dækker", skriver Solvej Balle og Christina Hesselholdt. Det interessante er selvfølgelig, i det mindste i denne sammenhæng, at de to redaktører ikke nævner kortprosaen når de skriver om det fragmentariske og det punktuelle og om at punktromanen er blevet beskyldt for at være en "light-roman eller en light-digtsamling". De skrev lederen blot et år før ordet kortprosa, som Lars Bukdahl skrev, lå på tungen af tidsånden, og det faktum understreger at ordet vandt indpas hos forfattere og litterater nærmest fra den ene dag til den anden. Omdrejningspunktet i dette nummer af Den Blå Port er Kjærsti Skjeldals artikel "Det voksne barn må have et navn. Punktroman er godt og misvisende". I sin artikel, som Christina Hesselholdt i øvrigt oversatte, skriver Kjærsti Skjeldal om punktromanen i Norge, og når man gør det så er Paal-Helge Haugens Anne uomgængelig. Og man får da også nemt den tanke at artiklen blev trykt i Den Blå Port af Balle og Hesselholdt på baggrund af en interesse for Anne - og for en række andre norske punktromaner som Skjeldal nævner og dermed introducerer for den danske litterære offentlighed.

Christina Hesselholdt havde oversat Paal-Helge Haugens punktroman nogle år tidligere, i 1992. Det er ganske påfaldende at en bog som Haugens Anne bliver oversat til dansk, og ikke mindst at den bliver det 24 år efter udgivelsen. Man kunne sagtens forstille sig at Anne kunne være blevet oversat da bogen blev udgivet i 1968. Den vakte opsigt i Norge, og fik blandt andet Norsk kulturråds pris, og det ville have givet god mening at præsentere den i Danmark med en oversættelse kort efter udgivelsen. Det skete ikke. Efter snart sagt alle gængse standarder er Anne en smal bog, og det er ikke urimeligt at antage at folk der måtte have interesse for bogen, kunne læse den på norsk. Der er med andre ord ikke ret mange gode grunde til at udgive Haugens Anne i 1992. Den eneste grund jeg kan komme i tanke om, er at bogen har betydet noget særligt for nogle personer. Valget af forlag understreger denne tese. Anne udkom på Forlaget Basilisk, hvilket ikke er uden betydning. Per Aage Brandt, der fra Forfatterskolens oprettelse underviste her, har været tilknyttet Basilisk siden forlagets oprettelse i 1983, Basilisk udgiver Forfatterskolens skriftserie Legenda, og Basilisk har siden 1999 udgivet Forfatterskolens Afgangsantologi. Majse Aymo-Boot, Peter Højrup, René Jean Jensen, Martin Larsen og Pejk Malinovski har siden år 2000 siddet i redaktionen. De har alle gået på Forfatterskolen. Der er med andre ord tætte bånd mellem Forfatterskolen og Forlaget Basilisk. Man kan næsten se udgivelsen af Haugens punktroman som en litteraturpolitisk markering eller som et indirekte manifest for nogle af de yngre forfattere i kredsen omkring Forfatterskolen i begyndelsen af 1990'erne, lige før de selv begyndte at udgive kortprosa: 'Det er det her vi læser, og det er det her vi er inspirerede af', kunne en underliggende præmis for udgivelsen lyde. I hvert fald er det påfaldende at oversættelsen og udgivelsen af den næsten 25 år gamle bog passer så godt med det der sker, og det der skal til at ske i dansk litteratur. Det ligner en tanke. ${ }^{9}$

At det var Christina Hesselholdt der oversatte Anne, er heller ikke uden betydning. Til Anne Toft og Dorte Øberg, der i 1997 udgav Det litterære væksthus om Forfatterskolen, har Hesselholdt fortalt at hun ikke kendte Haugen da hun skrev Køkkenet, gravkammeret og landskabet, men at hun oversatte Anne sideløbende med at hun skrev sin anden bog Det skjulte (Toft og Øberg 1997: note 32). Ved samme lejlighed fortæller Hesselholdt også at punktromanen er en væsentlig inspirationskil- 
de, og Toft og Øberg refererer hende også for at have nævnt en indirekte påvirkning fra Haugen gennem læsningen af Merete Morken Andersens Haugen-inspirerede punktroman Fra - og dermed fik vi nævnt en femte norsk forbindelse: kvindelige norske punktromanforfattere eller kortprosaister som fx Merete Morken Andersen, Eldrid Lunden og Cecilie Løveid.

Især Merete Morken Andersen, der selv ved flere lejligheder har vedgået sig arv og gæld fra Haugens Anne, er værd at pege på som en inspiration. Hun bliver derfor den femte norske inspiration for dansk kortprosa. I et e-mail-interview til det norske tidsskrift Bøygen, nr. 3 fra 2003, har Christina Hesselholdt igen peget på Morken Andersens første roman, Fra fra 1988, som en inspiration. Stefan Andreas Sture, der interviewede Hesselholdt, spørger med udgangspunkt i det faktum at Hesselholdt tidligere har nævnt Haugens Anne og Ulvens forfatterskab som inspirationskilder, om hun følger med i norsk litteratur, og om norsk litteratur har haft betydning for hende. Hesselholdt svarer at hun før sit egentlige forfatterskab havde skrevet digte, men først for alvor kom i gang som forfatter da hun opdagede den norske punktroman: "Da jeg oppdaget den norske punktromanen på sluttet av åttitallet, først Morken Andersens "Fra" og siden Haugens "Anne", hadde det en kolossal frigjørende effekt på min skrivning og gjorde meg i stand til å skrive min første bok: "Køkkenet, gravkammeret \& landskabet"; omtrent samtidig leste jeg "Gravgraver" (av Tor Ulven) [...] Jeg fulgte med i norsk litteratur mens jeg var redaktør på Den Blå Port og leste nordiske tidsskrifter som en del av mitt arbeide" (citeret efter http://parergonarkiv.blogspot. com). Igen peger Hesselholdt altså på Merete Morken Andersen og Paal-Helge Haugen som igangsættende inspirationer for sit forfatterskab. Til forskel fra oplysningerne hun har givet Dorte Øberg og Anne Toft, oplyser Hesselholdt i dette interview at hun havde læst både Morken Andersens Fra og Haugens Anne før sin egentlige debut som forfatter. Hvilken oplysning der er den korrekte, er ikke til at afgøre, og det er heller ikke så væsentligt som det faktum at den norske punktroman spiller en rolle for hendes tidlige forfatterskab. Det har hun vedgået ved flere lejligheder.

Merete Morken Andersen indleder Fra med et motto som hun har hentet hos Virginia Woolf: "But observe how dots and dashes are beginning, as I walk, to run themselves into continuous lines" (Andersen 1988: 5). Mottoet er et citat fra Woolfs The Waves fra 1931. Bernard er i kapitlet hvor formuleringen står at læse, i Rom. Han gør sig umiddelbart inden den korte passage som Morken Andersen citerer, følgende tanker: "Jeg har fundet på tusindvis af historier; jeg har fyldt utallige notesbøger med vendinger, der skal kunne bruges, når jeg har fundet den sande historie, som alle disse vendinger viser hen til. Men jeg har endnu aldrig fundet den historie. Og jeg begynder at spørge: Findes der historier?" (Woolf 1994: 117). Findes der historier? Det gør der muligvis, men kun historier der består af prikker og streger der løber sammen til linjer, samtidig med at de er prikker og streger. Sådan er det for Bernard i Woolfs roman, og sådan er det i punktromanen. Men Morken Andersens motto er en prik i en sammenhæng. Sammenhængen i Woolfs bog lyder sådan her i dansk oversættelse:

64 Her spadserer jeg alene frem og tilbage på denne terrasse uden at orientere mig. Men læg mærke til, hvordan prikker og streger, mens jeg går, begynder at løbe sammen til ubrudte 
linier; hvordan tingene mister den nøgne, den særlige identitet, de hver især havde, da jeg gik op ad disse trin. Den store røde krukke er nu en rødlig streg i en bølge af gulligt grønt. Verden begynder at bevæge sig forbi mig ligesom hækkens volde, når toget sætter i gang, ligesom havets bølger, når en damper sejler. Jeg bevæger mig også, kommer med i det almindelige sammenhængende forløb, hvor det ene følger det andet og det virker uundgåeligt, at træet kommer, så telegrafpælen, så åbningen i hækken. Og samtidig med at jeg bevæger mig, omgivet, indoptaget og deltagende, begynder de sædvanlige vendinger at boble op, og jeg har lyst til at befri disse bobler gennem faldlemmen i mit hoved, og derfor styrer jeg mine skridt hen mod den mand, hvis nakke forekommer mig bekendt. (Woolf 1994: 117f)

Bevægelsen i den mesterlige passage går fra vendinger, phrases, der skal bruges i den sande historie - the story to end all stories, som det hedder i den engelske original, gennem en tvivlen på historiens eller fortællingens mulighed i det hele taget, til en situation hvor prikkerne og stregerne, det vil sige vendingerne, danner linjer, det vil sige historier, men idet de gør det, mister prikkerne og stregerne deres identitet når de ophæves eller indoptages i fortællingens linjer, det sammenhængende forløb, der til sidst igen opløses i vendinger der bobler op og dermed igen bliver til prikker og streger i stedet for linjer. Bernard må styre sine skridt i en bestemt retning for at befri sig fra boblerne, han må åbne en faldlem i sit hoved.

Populært sagt er punktromanen - og det gælder både Haugens Anne og Andersens Fra - et forsøg på både at holde teksten åben for både punkter og linjer, på en gang. Som man kan se er Merete Morken Andersens motto et punkt af et længere (på én gang punktuelt og lineært) forløb som man kan finde hvis man kan lokalisere citatet (der i bogen blot er tilskrevet Virginia Woolf uden henvisning til værket det optræder i). Mottoet passer ikke blot fint på Fra og på punktroman-formen, selve udklipsteknikken er næsten også emblematisk for punktromanen: Citatet fungerer som citat, men det indgår også i en sammenhæng der også er oplysende. Ydermere kan man næsten læse mottoet som en kommentar til et kendt norsk citat, Jan Erik Volds bemærkning om at "Poesi er punkt, prosa er linje", hvilket muligvis er en af grundene til at Merete Morken Andersen valgte netop dette motto, for så er linjen mellem norsk 60'er-kortprosa og den nye udgave af punktroman ført igennem. ${ }^{\text {Io }}$

Hvordan kom disse norske inspirationer så til Danmark? Og hvorfor blev andre end Christina Hesselholdt også inspirerede af norsk prosa i 1990'ernes anden halvdel? Et muligt svar har Bukdahl i Generationsmaskinen. Han skriver:

16 Christina Hesselholdts debutroman, Køkkenet, gravkammeret og landskabet, 1991, kan gerne få æren af at stå som værket, der startede hele halvfemsergenerationshistorien. Det var den, der åbnede opmærksomme læseres øjne for, at der nu skete noget nyt. Samtidig var det også den der gav stikordene - uden selv eksplicit at have fremsagt dem - til de første pædagogiske og karikerende fikseringer: Minimalisme og Lyrisk prosa. (Bukdahl 2004: 73f)

Bukdahl har ret når han udpeger Hesselholdts første bog, eller måske nærmere første bøger, som helt centrale for den litterære udvikling i i Danmark i 1990'erne. Og 
disse bøger var inspirerede af norsk litteratur. Der er jo naturligvis i denne sammenhæng det lille aber dabei at ingen af disse bøger er kortprosa-bøger. De er nærmere punktromaner, og de er inspirerede af punktromaner. Det nærmeste Hesselholdt i bogform er kommet kortprosa-formen er Hovedstolen fra 1998. Ikke desto mindre var det nye, der for alvor blev synligt med Hesselholdts første bøger at det kunne lade sig gøre at skrive kort uden at skrive digte, at også i prosaen var det muligt at have luft på siden. Det har givetvis været en inspiration for andre forfattere i Hesselholdts generation og for de lidt yngre, som kom umiddelbart efter - og skrev kortprosa i stor stil. Året inden Hesselholdts første bog havde Solvej Balle udgivet en bog som nærmere kunne gøre krav på at være en lille kortprosa-samling. Det er naturligvis \& fra 1990 jeg tænker på. \& vakte ikke megen opsigt, og Solvej Balle fik først betydning i dansk 90'er-litteratur med Ifølge loven fra 1993, så selv om hun tidligt skrev kortprosa er det ikke hende der er den betydningsfulde skikkelse i dansk kortprosa. ${ }^{\text {II }}$ Det er Christina Hesselholdt. Det var hende der med sine første bøger for alvor satte kortformen i søen i dansk litteratur. Og jeg tror at det var hendes korte former der sejlede videre og hos andre forfattere blev til kortprosa-bølgen i dansk litteratur. Man kan altså lade historien om dansk kortprosa begynde med norsk litteratur. Det betyder ikke at man ikke også skal lade den begynde alle mulige andre steder. Det skal man.

\section{Noter}

I Jeg har valgt at lade kortprosaen være emnet her. Man kunne også, tror jeg, udstrække perspektivet: Norske inspirationer i nyere dansk prosa. Kortprosaen bliver med andre ord det eksplicitte fokus for denne artikel, men ved siden af eller under behandlingen af dette fokus fører jeg også hele tiden en diskussion af hvad inspiration er, og en underligggende præmis for artiklen er at inspirationer kan være svære at kortlægge. De forløber kun sjældent i lige linjer, og kun sjældent er der tale om én inspiration, men i stedet om rækker af inspirationer. Som regel skal inspirationerne kortlægges som forgreninger i netværk eller sammenløb af forskellige skrivemåder i en tekst eller i et forfatterskab. Et forenklet eksempel kunne lyde: Forfatteren A har ikke læst forfatteren $B$, men det har forfatteren $C$, som er inspireret af forfatter B, og forfatteren C er en vigtig inspiration for forfatteren A. Er forfatteren A da inspireret af forfatteren B? Det kan man vel ikke sige, men der kan godt være forbindelseslinjer mellem forfatteren A's tekster og forfatteren B's. Sådanne forbindelseslinjer kommer jeg også til at beskæftige mig med her.

2 Den ikke eksplicitte nævnte, men tydelige henvisning til Franz Kafka i Morten Søndergaards kortprosatekst er naturligvis henvisningen til Kafkas korte prosatekst: "Vor dem Gesetz", på dansk "Foran loven", fra 1919. I denne tekst kommer der som bekendt en mand fra landet for at bede om adgang til loven. Dørvogteren giver ikke manden fra landet tilladelse til at træde ind, og han lader ham forstå at der bag ham er en række af dørvogtere der fra sal til sal bliver mægtigere og mægtigere. Manden fra landet venter i mange år og får til sidst, da dørvogteren endegyldigt lukker døren, at vide at kun han ville have kunnet komme ind gennem denne dør.

3 Der er naturligvis altid undtagelser fra generaliseringer af denne art. En undtagelse er et særnummer af tidsskriftet Synsvinkler fra 1999. Nummeret hed DARSK, og bag den lidet skønne, endsige mundrette titel gemte sig: DAnsk litteratur i halvfemserne - noRSK nittitalslitteratur. 
Nummeret var redigeret af Astrid Fosvold og Ulrik Lehrmann. Det udsprang, kan man læse i forordet, af et undervisningsforløb om norsk og dansk samtidsprosa ved Syddansk Universitet. De fleste af artiklerne handler om enten norsk eller dansk samtidslitteratur og altså ikke om dansk og norsk litteratur.

4 Man kan godt finde eksempler på at ordet kortprosa har været brugt om kort prosa i Danmark før slutningen af 1990'erne. I 1971 udgav Jørgen Dines Johansen 2 bind af Dansk kortprosa og to bind af Analyser af dansk kortprosa. Teksterne i disse bøger har ikke noget at gøre med det der siden slutningen af 90'erne er blevet kaldt kortprosa. Der er nærmere tale om noveller. I 1983 blev der i Odense holdt en konference med titlen "Kortprosa i Norden", og i den forbindelse skrev en tysk skandinavist, Otto Oberholzer, om kortprosa i artiklen "Kortprosa som litterär genre i historiskt och poetologiskt perspektiv". Og, som han bemærker i sin artikel, så er betegnelsen kortprosa i konferencens titel problematisk fordi den omfatter "all prosalitteratur som är kortare än roman eller berättelse" (Oberholzer 1983: 13). Oberholzer forsøger selv en mere brugbar definition, og han lykkes fint med at tegne linjer fra 1890'erne og frem i den skandinaviske litteratur, men af gode grunde fanger hans begreb om kortprosa ikke 1990'ernes kortprosa. De litterære eksempler er primært hentet omkring århundredeskiftet til det 20. århundrede. Bo Hakon Jørgensen udgav i 1991 antologien Fortællinger og kortprosa 1877-1907 i Det danske Sprog- og Litteraturselskabs klassikerserie. Igen indgår ordet kortprosa i titlen, men, som samme titel angiver, er det igen en anden periode antologien dækker, og derfor er det også en anden tradition der bliver beskrevet - en tradition der dog har en del tilfælles med udvalget af de tidlige tekster i Brixvold og Jørgensens første antologi.

5 Jeg har i en antologi over dansk kortprosa, Kortprosa 1990-2003, udfoldet Höllerers syv punkter og foreslået punkterne som udgangspunkt for en læsestrategi i forhold til kortprosaen. Andre, fx Gitte Mose, har også henvist til Höllerer.

6 Jeg har i Kortprosa 1990-2003 forsøgt at skelne mellem en minimal-realistisk og en fantastisk (eller fabulerende) kortprosa i Danmark i 1990'erne. Kortprosaen i 1990'erne var nemlig ikke blot én størrelse, men mindst disse to retninger som jeg i antologien har forsøgt at illustrere ved inspirationer fra på den ene side Raymond Carver og Ernest Hemingway og på den anden side J.L. Borges og Franz Kafka - ja, jeg har også forsøgt mig med den slags sammenligninger. Det er primært i forhold til den minimal-realistiske kortprosa jeg peger på inspirationer fra norsk kortprosa.

7 Jeg skriver om Askildsens korrektion i et interview med Askildsen (Ipsen 2001).

8 Det er påfaldende at Gitte Mose i den ellers fine artikel "Fortællinger i glimt - dansk kort-kortprosa i 1990erne" mener at nummeret er et temanummer om det romantiske. Hun skriver: "Som det jævnligt bliver bemærket har 90erne været særligt optaget af romantikken. Et helt nummer af Den Blå Port i Balles og Hesselholdts redaktørperiode var på grund af deres explicitte interesse for traditionen ikke overraskende viet artikler om det romantiske fragment, oversættelser af udvalgte fragmenter af Schlegel og Novalis, samt en artikel om punktromanen som genre" (Mose 2001: 11). Interessen går den anden vej, fra punktromanen til romantikken. Balle og Hesselholdt bliver interesserede i fragmentet - og ikke nødvendigvis i romantikken som sådan fordi de er interesserede i punktromanens fragmenterede form. Ikke omvendt. I lederen skriver Balle og Hesselholdt da også at det er Skjeldals artikel om punktromanen der har inspireret til inddragelsen af de romantiske fragmenter.

9 Det ligner også en tanke, en antydning af en inspiration, at Anne-Marie Mai bad netop PaalHelge Haugen om at skrive afsnittet om Christina Hesselholdt til 4. udgave af Danske digtere $i$ det 20. århundrede. Paal-Helge Haugen antyder en sammenhæng mellem Hesselholdts forfatter- 
skab og punktromanen i sit essay. Han skriver blandt andet om Køkkenet, gravkammeret \& landskabet at bogen er en roman hvor forløbet bliver "reduceret til sine mindste konstruktionsdele", og den fremtræder derfor "som en særegen sammensmeltning af poesiens stasis og den episke prosas dynamik" (Haugen 2000: 523). Det er en beskrivelse af punktromanen der, som Haugen beskedent skriver, er: "et nydannet begreb, der stammer fra norsk litterær praksis i slutningen af 1960'erne" (ibid.).

Io Jan Erik Vold brugte formuleringen som overskrift til en tekst i samlingen kykelipi fra 1969. Teksten, der ikke er særligt kendt i Danmark lyder, med titlen i anførselstegn, som var det, hvilket det måske også er, et citat: “'Prosa er linje, poesi er punkt' // Tre bobler fra bunnen, siden / ikke noe mere. Det var hele diktet. // Jeg gentar: Tre bobler / fra bunnen, siden ikke noe mer. I prosa // ville det lyde slik: Tre bobler fra bunnen, / siden ikke noe mer. Situasjonen kommer aldri // igjen: Jan Erik Vold ved vannet, det / vannet, den stubben og tre bobler som bryter // den svarte overflaten, de tre boblene, i den / rekkefølgen, dannede den trekanten - og så // borte igjen, kosmosklokka har tikket / videre. I poesi lød det altså slik: // Tre bobler fra bunnen, siden / ikke noe mer." (Vold 1969: 98f). Poesi eller prosa? Ja, bedøm det selv.

II Og så alligevel: Efter det spektakulære gennembrud med Ifølge loven fik man - og det vil sige både forfattere og litterater - naturligvis også øje på \&, og bogen kan dermed have fået en forsinket virkningshistorie.

\section{Litteratur:}

Andersen, Merete Morken: Fra, Oslo: Gyldendal Norsk Forlag, 1988.

Askildsen, Kjell: Samlede noveller, Oslo: Forlaget Oktober, 1999.

Bukdahl, Lars: "Ritter-Sport-Generationen. Katalog over et godt, praktisk, kvadratisk årti”, Kritik, nr. 141, 1999.

Bukdahl, Lars: Generationsmaskinen, København: Borgen, 2004.

Haugen, Paal-Helge: "Christina Hesselholdt”, i Anne-Marie Mai (red.): Danske digtere i det 20. århundrede, København: Gads Forlag, 2000.

Hesselholdt, Christina: "Vi, sammenblandede”, Den Blå Port, nr. 22, 1992.

Höllerer, Walter: "Die Kurze Form der Prosa", Akzente 2, 1962.

Ipsen, Max: “Flige af vor tids mentale landskab' - en samtale med Kjell Askildsen”, Standart, nr. 3, 2001.

Ipsen, Max: Kortprosa 1990-2003, Århus: Systime, 2003.

Jørgensen, Bo Hakon: Fortællinger og kortprosa, København: Borgen, 1991.

Mose, Gitte: "Fortællinger i glimt - dansk kort-kortprosa i 1990erne", Norsk Litteraturvitenskapelig Tidsskrift, nr. 1, 2001.

Oberholzer, Otto: "Kortprosa som litterär genre i historiskt och poetologiskt perspektiv", i Mogens Brønsted (red.): Kortprosa i Norden, Odense: Odense Universitetsforlag, 1983.

Skjeldal, Kjærsti: “Det voksne barn må have et navn”, Den Blå Port, nr. 36, 1996.

Skyum-Nielsen, Erik: Engle i sneen, København: Gyldendal, 2000.

Solstad, Dag: "Vi vil ikke gi kaffekjelen vinger", i Svingstol, Oslo: Aschehoug, 1967a.

Solstad, Dag: "Det trivielle/det fantastiske - flukt/akseptasjon", Vinduet, nr. 2, 1967b.

Sture, Stefan Andreas: "Så mye som mulig av verden sparket inn i boken", http://parergonarkiv. blogspot.com, 2003. 
Søndergaard, Morten: At holde havet tilbage med en kost, København: Borgen, 2004.

Toft, Anne og Dorte Øberg: Det litterære væksthus, Odense: Odense Universitetsforlag, 1997.

Ulven, Tor: Fortæring, Oslo: Gyldendal Norsk Forlag, 1991.

Vold, Jan Erik: kykelipi, Oslo: Gyldendal Norsk Forlag, 1969.

Woolf, Virginia: Bølgerne, København: Rosinante, 1994 (1931).

Aagenæs, Bjørn: "Norsk kortprosa (60-90)”, Dansk noter, nr. 3, 1995. 